\title{
Tissue Concentrations of Vasoactive Intestinal Peptide Are Affected by Peritonitis-Induced Sepsis and Hemofiltration in Pigs
}

\author{
J. KUNCOVÁ ${ }^{1}$, J. CHVOJKA ${ }^{2}$, R. SÝKORA ${ }^{2}$, J. ŠVIÍGLEROVÁ ${ }^{1}$, M. ŠTENGL ${ }^{1}$, \\ L. NALOS ${ }^{1}$, A. KROUŽECKÝ ${ }^{2}$, M. MATĚJOVIČ \\ ${ }^{1}$ Department of Physiology and ${ }^{2}$ First Medical Department, Charles University in Prague, Faculty \\ of Medicine and Teaching Hospital in Plzeň, Plzeň, Czech Republic
}

Received June 30, 2010

Accepted October 21, 2010

On-line March 14, 2011

\section{Summary}

Vasoactive intestinal peptide (VIP) is a neuropeptide released from the autonomic nerves exerting multiple antiinflammatory effects. The aim of the present study was to investigate the impact of severe sepsis and hemofiltration in two settings on plasma and tissue concentrations of VIP in a porcine model of sepsis. Thirty-two pigs were divided into 5 groups: 1) control group; 2) control group with conventional hemofiltration; 3) septic group; 4) septic group with conventional hemofiltration; 5) septic group with high-volume hemofiltration. Sepsis induced by faecal peritonitis continued for 22 hours. Hemofiltration was applied for the last 10 hours. Hemodynamic, inflammatory and oxidative stress parameters (heart rate, mean arterial pressure, cardiac output, systemic vascular resistance, plasma concentrations of tumor necrosis factor- $a$, interleukin-6, thiobarbituric acid reactive species, nitrate + nitrite, asymmetric dimethylarginine) and the systemic VIP concentrations were measured before faeces inoculation and at 12 and 22 hours of peritonitis. VIP tissue levels were determined in the left ventricle, mesenteric and coronary arteries. Sepsis induced significant increases in VIP concentrations in the plasma and mesenteric artery, but it decreased peptide levels in the coronary artery. Hemofiltration in both settings reduced concentrations of VIP in the mesenteric artery. In severe sepsis, VIP seems to be rapidly depleted from the coronary artery and, on the other hand, upregulated in the mesenteric artery. Hemofiltration in both settings has a tendency to drain away these upregulated tissue stores which could result in the limited secretory capacity of the peptide.
\end{abstract}

\section{Key words}

VIP plasma levels • Severe sepsis • Coronary artery • Mesenteric artery $\bullet$ Heart

\section{Corresponding author}

J. Kuncová, Department of Physiology, Charles University, Faculty of Medicine in Plzeň, Lidická 1, 30166 Plzeň, Czech Republic. Fax: +420 377593 349. E-mail: jitka.kuncova@lfp.cuni.cz

\section{Introduction}

Vasoactive intestinal peptide (VIP) is an octacosapeptide released from the autonomic nerves acting as a nonadrenergic noncholinergic neuro-transmitter or neuromodulator. Significant concentrations of VIP are present in the gastrointestinal, cardiovascular, respiratory and urogenital systems (Lundberg 1996). Many systemic and pulmonary blood vessels are innervated by nerve fibres releasing VIP that causes profound and long-lasting relaxation of the vascular smooth muscle (Champion et al. 1996). In the mammalian heart, VIP immunoreactivity has been demonstrated in cholinergic neurones that release the peptide upon high frequency electrical stimulation of the vagus nerve and mediate positive chronotropic effect known as vagal tachycardia (Henning and Sawmiller 2001). In addition, VIP seems to have protective action during acute myocardial ischemia acting as a free-radical scavenger, decreasing myocardial release of creatinine kinase and improving cardiac perfusion (Kalfin et al. 1994).

Besides its role in the regulation of the major cardiovascular variables, VIP emerges as an important 
contributor to neuroimmune crosstalk: nerve fibres containing VIP supply lymphoid organs (Bellinger et al. 1990, Kulkarni-Narla et al. 1999), white blood cells express VIP receptors (Ganea and Delgado 2002) and might produce also the peptide itself especially under inflammatory stimuli (Kawashima et al. 2007). VIP attenuates deleterious consequences of sepsis-induced macrophage activation by inhibiting tumor necrosis- $\alpha$ and interleukin-6 production and stimulating release of antiinflammatory cytokine IL-10 (Delgado et al. 1999). Furthermore, VIP is involved in neutrophil recruitment in different target organs (Martínez et al. 2006), inhibits tissue factor expression in monocytes (Lv et al. 2009) and seems to be protective even in the later phases of sepsis by limiting secretion of the high mobility group box 1 protein (Chorny and Delgado 2008). In vivo data documented VIP-induced protection from lethal peritonitis in mice and increased susceptibility to death from endotoxemia in VIP gene knockout mice (Hamidi et al. 2006). In septic patients, increased VIP systemic levels have been demonstrated (Brandtzaeg et al. 1989). Several recently published papers suggest that VIP could be an attractive candidate for the development of therapies against severe sepsis and septic shock (Martínez et al. 2005, Toscano et al. 2010).

Severe sepsis is characterized by dysregulated host response to infection associated with an excessive production and release of both pro- and antiinflammatory cytokines and consecutive multiple organ dysfunction (Hotchkiss and Karl 2003). Therapeutic strategies aiming at reducing cytokine levels elevated by the systemic inflammation in sepsis tested so far challenged either single specific inflammatory agent using monoclonal antibodies or acted nonspecifically, by eliminating excess of mediators released into the blood compartment in relation to the septic status (Ronco et al. 2003). Whereas single-substance strategies did not show anticipated beneficial effects and had even harmful consequences (Dinarello 2001), hemofiltration and related techniques seem to be more promising, particularly with regard to the hemodynamic stability and need for vasopressors support (Ratanarat et al. 2005). In spite of these potential clinical benefits, so far reported impact of hemopurification techniques on the plasma levels of various noxious substances and downstream biological pathways implicated in sepsis pathophysiology is still equivocal (Reeves et al. 1999, Sykora et al. 2009). In addition, considerable attention has been focused on benefits of hemofiltration, whereas less attention has been paid to the potential for increased risk. Indeed, nonselective detoxification not only might remove harmful substances but also water soluble molecules with potentially beneficial effects.

The aim of the present study was to verify sepsis-induced elevations in plasma VIP levels in a clinically relevant porcine model of hyperdynamic septic shock induced by fecal peritonitis and to investigate putative impact of hemofiltration in two settings on the plasma and tissue concentrations of VIP.

\section{Methods}

Thirty-two domestic pigs (Farm Mladotice, Czech Republic) of both sexes weighing 30-45 kg were studied. All experiments were conducted in accordance with the relevant Guidelines of the Czech Ministry of Agriculture for Scientific Experimentation on Animals and the European Directive for the Protection of Vertebrate Animals Used for Experimental and Other Scientific Purposes (86/609/EEC) and were approved by the University Committee for Experiments on Laboratory Animals (Charles University, Czech Republic). Pigs were divided into 5 groups: 1) control group without hemofiltration $(n=6)$; 2) control group subjected to conventional hemofiltration (ultrafiltration rate $35 \mathrm{ml} / \mathrm{kg} / \mathrm{hr}, \mathrm{n}=4)$; 3) septic group without hemofiltration $(\mathrm{n}=8)$; 4) septic group with conventional hemofiltration (ultrafiltration rate $35 \mathrm{ml} / \mathrm{kg} / \mathrm{hr}, \mathrm{n}=6$ ); and 5) septic group undergoing high-volume hemofiltration (ultrafiltration rate $100 \mathrm{ml} / \mathrm{kg} / \mathrm{hr}, \mathrm{n}=8$ ). The anesthesia, surgery and physiological measurements were performed as described recently (Chvojka et al. 2008). Briefly, anesthesia was induced by propofol (1-2 $\mathrm{mg} / \mathrm{kg})$ and ketamine $(2 \mathrm{mg} / \mathrm{kg})$ and maintained by thiopental $(5 \mathrm{mg} / \mathrm{kg} / \mathrm{h})$ and fentanyl $(5 \mu \mathrm{g} / \mathrm{kg} / \mathrm{h})$. Animals were mechanically ventilated with arterial $\mathrm{pCO}_{2}$ maintained between 4 and $5 \mathrm{kPa}$. Central venous catheter, pulmonary artery thermodilution catheter, femoral artery and femoral vein catheters were inserted for drug and fluid infusion, cardiac output and blood pressure recordings and hemofiltration access, respectively. Noradrenaline was administered to maintain mean arterial pressure greater than or equal to $65 \mathrm{mmHg}$. Fluid resuscitation was guided by continuous cardiac filling pressures and intrathoracic blood volume measurements.

The hemofiltration was performed on the MultiFiltrate system (Fresenius Medical Care AG \& Co. KGaA, Bad Homburg, Germany) with a synthetic 
membrane (Ultraflux AV600S; the high-flux polysulphone filter, surface $1.4 \mathrm{~m}^{2}$, cut off up to 30,000 Dalton, Fresenius). Continuous veno-venous hemofiltration and high-volume continuous veno-venous hemofiltration with zero-balanced treatment were set at ultrafiltration rates of 35 and $100 \mathrm{ml} / \mathrm{kg} / \mathrm{hour}$, respectively. Blood flow rate was set at $200 \mathrm{ml} / \mathrm{min}$. Bicarbonate buffered (35 mmol/l) replacement fluid (Medisol Bi-4, solution for hemofiltration, Medites Pharma, Rožnov pod Radhoštěm, Czech Republic) was administered $50 \%$ in predilution and $50 \%$ in postdilution fashion. The replacement fluid was warmed to $39{ }^{\circ} \mathrm{C}$ in the MultiFiltrate, and the HOTLINE ${ }^{\circledR}$ Blood and Fluid Warmer (Smiths Medical, Herts, United Kingdom) was inserted on the venous return line to prevent an extracorporeal circuit-induced decrease in body temperature. Anticoagulation was achieved with an initial i.v. bolus $0.2 \mathrm{ml} / 10 \mathrm{~kg}$ of nadroparinum (Fraxiparine, Glaxo Group Ltd., Greenford, Middlesex, United Kingdom) for all experimental animals, including the control groups.

Baseline data were recorded after six hours of postsurgical stabilization period; peritonitis was induced by autologous faeces inoculation and second set of measurements was obtained 12 hours later. In hemofiltration groups, continuous conventional or highvolume hemofiltration was started at 12 hours and continued for additional 10 hours till the end of experiment. The final set of data, blood and ultrafiltrate samples were taken in the end of hemofiltration procedure, i.e. at 22 hours of peritonitis. The animals were euthanized by $\mathrm{KCl}$ injection under deep anaesthesia.

Hemodynamic measurements included heart rate (electrocardiography), systolic and diastolic blood pressures (electronic pressure transducer), and cardiac output (thermodilution technique). Systemic vascular resistance was calculated as (mean arterial pressure central venous pressure)/cardiac output. Concentrations of inflammatory cytokines TNF- $\alpha$ and IL-6 in the plasma were determined by commercial immunoassay diagnostic kits (Biosource swine TNF- $\alpha$ ELISA, Biosource International, Inc., Camarillo, CA, USA and Quantikinine, Porcine IL-6 immunoassay, R\&D Systems, Inc., Minneapolis, MN, USA, respectively). Oxidative and nitrosative stress was evaluated by determination of arterial thiobarbituric acid reactive species concentrations (TBARS) by spectrophotometric method (Chvojka et al. 2008), arterial nitrate + nitrite (NOx) concentrations (colorimetric method; Matejovic et al. 2004), and asymmetric dimethylarginine (ADMA; commercial enzyme-linked immunosorbent assay kits ADMA® ELISA, DLD Diagnostika GmbH, Hamburg, Germany).

VIP levels in the arterial plasma, ultrafiltrate and extracts of the proximal left coronary artery, mesenteric artery and left ventricular wall were determined by commercial radioimmunoassay kits (Phoenix Pharmaceuticals Inc., Burlingame, CA, USA) after extraction and purification with equilibrated SEP-Pak C18 cartridges (RK-SEPCOL-1; Phoenix Pharmaceuticals Inc., Burlingame, CA, USA).

Results are presented as median and $25^{\text {th }}$ and $75^{\text {th }}$ percentiles. TNF- $\alpha$, IL-6, TBARS, NOx, ADMA and VIP levels in the blood or plasma were normalized for plasma protein content to correct dilutional effects resulting from volume resuscitation (Matejovic et al. 2004). Tissue concentrations of VIP were expressed in $\mathrm{ng} / \mathrm{g}$ or $\mathrm{pg} / \mathrm{g}$ tissue wet weight where appropriate. Statistical differences were analyzed using software package STATISTICA Cz, version 7 (StatSoft Inc., 2004, Prague, Czech Republic). After testing for the normality of distribution and homogeneity of variances, comparisons of parametric variables were made using two-way ANOVA or repeated measures ANOVA followed by post hoc Fisher's Least Significant Difference test. Nonparametric variables were compared using the Friedman ANOVA on ranks or Kruskal-Wallis ANOVA where appropriate. The results were considered significantly different when $\mathrm{P}<0.05$.

\section{Results}

\section{Cardiovascular variables}

Hemodynamic parameters are listed in Table 1. There were no statistically significant differences in any of the measured variables among the five groups prior to induction of peritonitis (baseline). Inoculation of autologous faeces resulted in hyperdynamic septic circulation with a high cardiac output and low systemic vascular resistance. No significant impact of hemofiltration on the hemodynamic variables could be observed in the control pigs. Likewise, septic animals undergoing hemofiltration procedures in both settings did not display any additional differences in hemodynamic parameters compared to septic pigs without hemofiltration. 
Table 1. Systemic hemodynamics.

\begin{tabular}{|c|c|c|c|c|}
\hline & & Baseline & 12 hours & 22 hours \\
\hline$M A P$ & $C O N-N O H F$ & $91(86 ; 97)$ & $82(74 ; 83)$ & $80(74 ; 84)$ \\
\hline \multirow[t]{4}{*}[mmHg]{} & $\mathrm{CON}-\mathrm{CHF}$ & $95(89 ; 104)$ & $97(92 ; 102)$ & $89(77 ; 101)$ \\
\hline & $S E P-N O H F$ & $94(89 ; 103)$ & $95(88 ; 106)$ & $80(75 ; 97)$ \\
\hline & $S E P-C H F$ & $83(82 ; 92)$ & $90(84 ; 94)$ & $76(71 ; 80)$ \\
\hline & SEP-HVHF & $98(92 ; 106)$ & $88(78 ; 110)$ & $71(66 ; 81)^{*}$ \\
\hline $\mathrm{CO}$ & $C O N-N O H F$ & $85(80 ; 104)$ & $93(77 ; 99)$ & $79(67 ; 96)$ \\
\hline \multirow[t]{4}{*}[\mathrm{ml}\cdot\mathrm{kg}^{-1}\cdot\mathrm{min}^{-1}]{} & $C O N-C H F$ & $91(79 ; 97)$ & $81(71 ; 99)$ & $76(68 ; 85)$ \\
\hline & SEP-NO HF & $78(61 ; 90)$ & $105(97 ; 119)^{*}$ & $129(104 ; 180)^{*}$ \\
\hline & $S E P-C H F$ & $77(72 ; 81)$ & $130(114 ; 136)^{*}$ & $155(133 ; 164)^{*}$ \\
\hline & SEP-HVHF & $85(71 ; 104)$ & $110(102 ; 119)$ & $162(149 ; 168)^{*}$ \\
\hline$H R$ & $C O N-N O H F$ & $82(67 ; 85)$ & $92(83 ; 94)$ & $89(82 ; 93)$ \\
\hline \multirow{4}{*}[\operatorname{min}^{-1}]{} & $\mathrm{CON}-\mathrm{CHF}$ & $85(75 ; 95)$ & $106(103 ; 111)$ & $113(106 ; 122)$ \\
\hline & $S E P-N O H F$ & $53(52 ; 67)$ & $121(111 ; 136)^{*}$ & $166(158 ; 180)^{*}$ \\
\hline & $S E P-C H F$ & $75(65 ; 83)$ & $126(112 ; 128)^{*}$ & $144(133 ; 155)^{*}$ \\
\hline & $S E P-H V H F$ & $66(63 ; 81)$ & $112(108 ; 123)^{*}$ & $167(119 ; 173)^{*}$ \\
\hline$S V R$ & $C O N-N O H F$ & $2535(1761 ; 2823)$ & $2007(1924 ; 2084)$ & $2136(1922 ; 2283)$ \\
\hline \multirow[t]{4}{*}[\text{dyne.sec.}\mathrm{cm}^{-5}]{} & $C O N-C H F$ & $2355(2160 ; 2588)$ & $2551(2061 ; 2893)$ & $2296(1795 ; 2879)$ \\
\hline & $S E P-N O H F$ & $2756(2318 ; 2830)$ & $1779(1579 ; 1978)^{*}$ & $1001(795 ; 1643)^{*}$ \\
\hline & $S E P-C H F$ & $2127(1914 ; 2584)$ & $1260(1191 ; 1309)^{*}$ & $892(858 ; 1113)^{*}$ \\
\hline & SEP-HVHF & 2507 (2144; 2739) & $1891(1598 ; 1982)^{*}$ & $750(665 ; 974)^{*}$ \\
\hline
\end{tabular}

MAP, mean arterial pressure; $\mathrm{CO}$, cardiac output; $\mathrm{HR}$, heart rate; SVR, systemic vascular resistance in the control pigs without hemofiltration (CON-NO HF), control pigs with conventional hemofiltration (CON-CHF), septic pigs without hemofiltration (SEP-NO HF), septic pigs with conventional hemofiltration (SEP-CHF), septic pigs with high-volume hemofiltration (SEP-HVHF). ${ }^{*}$ Significant difference within each group vs baseline $(p<0.05)$. Data are median and $25^{\text {th }}$ and $75^{\text {th }}$ percentiles.

\section{Inflammation, oxidative and nitrosative stress}

Table 2 shows the systemic levels of TNF- $\alpha$, IL-6, TBARS, NOx and ADMA in the five groups. Significant differences were observed between the baseline and septic values. There were no significant changes in the monitored variables in the control animals over the time. Hemofiltration did not affect any of the measured parameters in both control and septic animals.

\section{VIP levels in the plasma, ultrafiltrates, and tissues}

In all control animals (both subjected and not to hemofiltration), systemic VIP concentrations did not markedly change over the time (data not shown). Sepsis led to significant elevations of the peptide levels in the arterial plasma that slightly declined toward the end of the experiment remaining still significantly higher than the baseline values (Fig. 1A). Similar trends were observed in septic pigs subjected to conventional and high-volume hemofiltrations.

VIP was detected in the ultrafiltrates from both conventional and high-volume hemofiltrations. Estimated cumulative losses of VIP into ultrafiltrate were $46 \mathrm{ng} / 10 \mathrm{~h}$ in the control animals subjected to conventional hemofiltration, $57 \mathrm{ng} / 10 \mathrm{~h}$ and $145 \mathrm{ng} / 10 \mathrm{~h}$ in septic pigs subjected to conventional and high-volume hemofiltration, respectively.

As shown in Figure 1B, concentrations of VIP in the coronary artery were significantly decreased in all septic pigs and they were not further affected by hemofiltration. Interestingly, there was a trend for conventional hemofiltration to reduce VIP levels in the coronary artery of the control animals $(\mathrm{P}=0.06)$. Mesenteric arteries isolated from the septic pigs not subjected to hemofiltration displayed significantly increased VIP levels compared to control pigs without hemofiltration (Fig. 1C). Hemofiltration resulted in $\sim 34 \%$ 
Table 2. Inflammation and oxidative/nitrosative stress.

\begin{tabular}{|c|c|c|c|c|}
\hline & & Baseline & 12 hours & 22 hours \\
\hline$I L-6$ & CON-NO HF & $1.8(1.2 ; 2.3)$ & $0.7(0.3 ; 1.2)$ & $1.2(0.5 ; 1.6)$ \\
\hline \multirow[t]{4}{*}{ [ng/g protein] } & $\mathrm{CON}-\mathrm{CHF}$ & $4.4(2.9 ; 7.1)$ & $1.5(1.1 ; 2.2)$ & $1.3(1.0 ; 1.4)$ \\
\hline & $S E P-N O H F$ & $2.7(1.6 ; 3.8)$ & $26.7(10,6 ; 29,2)^{*}$ & $86.3(26.6 ; 481.7)^{*}$ \\
\hline & $S E P-C H F$ & $2.2(0.6 ; 3.9)$ & $13.7(11.2 ; 21.7)^{*}$ & $128.0(47.4 ; 210.1)^{*}$ \\
\hline & $S E P-H V H F$ & $2.8(2.1 ; 6.4)$ & $36.4(19.0 ; 71.7)^{*}$ & $857.8(65.5 ; 1559.3)^{*}$ \\
\hline$T N F-\alpha$ & CON-NO HF & $0.8(0.7 ; 0.9)$ & $1.3(1.2 ; 1.5)$ & $1.4(1.2 ; 1.4)$ \\
\hline \multirow[t]{4}{*}{ [ng/g protein] } & $\mathrm{CON}-\mathrm{CHF}$ & $1.5(1.3 ; 1.6)$ & $2.0(1.5 ; 2.5)$ & $0.9(0.8 ; 1.1)$ \\
\hline & $S E P-N O H F$ & $1.4(1.1 ; 1.4)$ & $4.7(4.1 ; 6.4)^{*}$ & $12.8(4.9 ; 21.8)^{*}$ \\
\hline & $S E P-C H F$ & $1.0(0.4 ; 1.7)$ & $4.8(2.8 ; 7.2)^{*}$ & $13.5(8.9 ; 13.5)^{*}$ \\
\hline & $S E P-H V H F$ & $1.6(0.8 ; 5.6)$ & $6.8(4.6 ; 9.8)^{*}$ & $7.0(5.3 ; 12.3)^{*}$ \\
\hline TBARS & CON-NO HF & $16.8(16.4 ; 18.4)$ & $20.4(17.4 ; 27.8)$ & $22.8(16.3 ; 23.1)$ \\
\hline \multirow[t]{4}{*}{ [pmol/g protein] } & $\mathrm{CON}-\mathrm{CHF}$ & $19.2(17.8 ; 21.0)$ & $23.2(20.5 ; 24.6)$ & $23.2(21.7 ; 27.0)$ \\
\hline & $S E P-N O H F$ & $18.5(15.4 ; 21.1)$ & $46.6(39.1 ; 57.7)^{*}$ & $75.2(56.8 ; 98.1)^{*}$ \\
\hline & $S E P-C H F$ & $17.8(14.9 ; 19.3)$ & $43.1(34.7 ; 47.0)^{*}$ & $52.9(44.7 ; 78.2)^{*}$ \\
\hline & $S E P-H V H F$ & $17.1(15.2 ; 23.4)$ & $47.0(35.4 ; 53.8)^{*}$ & $83.6(52.8 ; 109.2)^{*}$ \\
\hline Nitrite + nitrate & CON-NO HF & $0.9(0.7 ; 1.2)$ & $0.6(0.5 ; 1.0)$ & $0.7(0.5 ; 1.1)$ \\
\hline \multirow[t]{4}{*}{ [umol/g protein] } & $\mathrm{CON}-\mathrm{CHF}$ & $1.0(0.6 ; 1.7)$ & $0.9(0.7 ; 1.1)$ & $0.8(0.6 ; 1.0)$ \\
\hline & SEP-NO HF & $0.7(0.6 ; 0.9)$ & $1.2(1.0 ; 1.5)^{*}$ & $1.3(1.0 ; 1.5)^{*}$ \\
\hline & $S E P-C H F$ & $0.6(0.5 ; 0.8)$ & $1.3(0.9 ; 1.7)^{*}$ & $1.1(1.0 ; 1.2)$ \\
\hline & $S E P-H V H F$ & $0.9(0.4 ; 1.5)$ & $1.7(1.3 ; 1.9)^{*}$ & $1.6(1.4 ; 1.6)$ \\
\hline$A D M A$ & CON-NO HF & $51.5(49.5 ; 53.5)$ & $47.0(45.0 ; 59.5)$ & $54.0(48.5 ; 62.5)$ \\
\hline \multirow[t]{4}{*}{ [nmol/g protein] } & $\mathrm{CON}-\mathrm{CHF}$ & $72.5(65.5 ; 79.8)$ & $53.5(44.5 ; 61.8)$ & $52.0(32.2 ; 83.3)$ \\
\hline & $S E P-N O H F$ & $58.5(47.2 ; 70.8)$ & $85.0(75.2 ; 92.8)^{*}$ & $68.0(48.5 ; 100.0)$ \\
\hline & $S E P-C H F$ & $49.0(42.5 ; 57.8)$ & $55.0(44.0 ; 79.5)$ & $76.0(40.8 ; 111.3)^{*}$ \\
\hline & SEP-HVHF & $62.0(48.3 ; 67.8)$ & $75.0(66.8 ; 115.3)^{*}$ & $94.0(65.3 ; 114.3)^{*}$ \\
\hline
\end{tabular}

IL-6, interleukin-6; TNF-a, tumor necrosis factor-a, TBARS, thiobarbituric acid reactive species; ADMA, asymmetric dimethylarginine concentrations in the plasma of the control pigs without hemofiltration (CON-NO HF), control pigs with conventional hemofiltration (CONCHF), septic pigs without hemofiltration (SEP-NO HF), septic pigs with conventional hemofiltration (SEP-CHF), septic pigs with high-volume hemofiltration (SEP-HVHF). "Significant difference within each group vs baseline $(\mathrm{p}<0.05)$. Data are median and $25^{\text {th }}$ and $75^{\text {th }}$ percentiles.

reduction in the tissue content of the peptide in the mesenteric arteries of the control animals $(\mathrm{P}<0.05$ vs controls without hemofiltration); in the septic pigs, hemofiltration led to arterial tissue levels not differing from the control values. VIP concentrations in the myocardial tissue did not differ among all groups (Fig. 1D).

\section{Discussion}

Effect of sepsis on VIP plasma and tissue levels

The present study addressed the impact of peritonitis-induced septic shock on VIP concentrations in the plasma and reports, for the first time, sepsis- and hemofiltration-related levels of VIP in the selected cardiovascular tissues of the pig. The results confirmed a transient increase in the systemic VIP concentrations previously reported in endotoxemic pigs, dogs and in human patients suffering from gram-negative septic shock (Brandtzaeg et al. 1989, Fuortes et al. 1988, Revhaug et al. 1985). The decline in VIP plasma concentrations between 12 and 22 hours of the sepsis duration could reflect the putative changes in a delicate balance between the synthesis of the peptide and its 
A
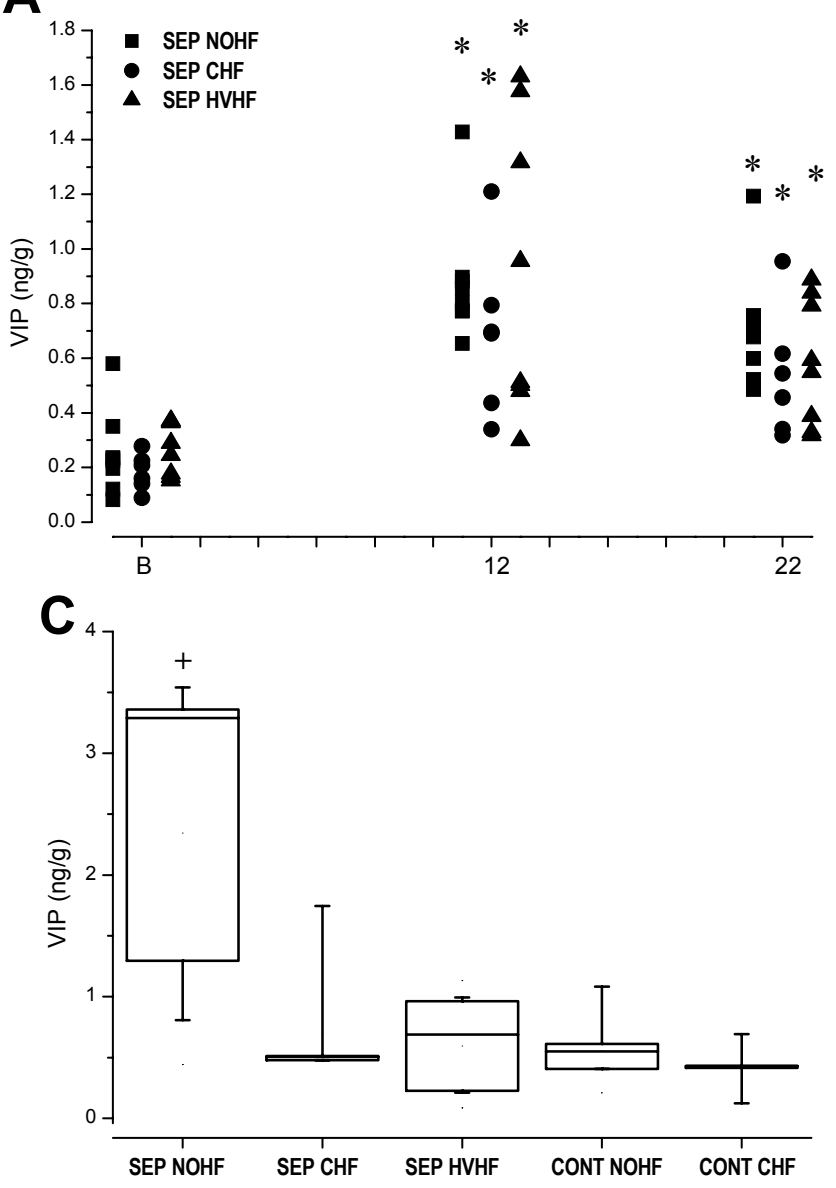

B

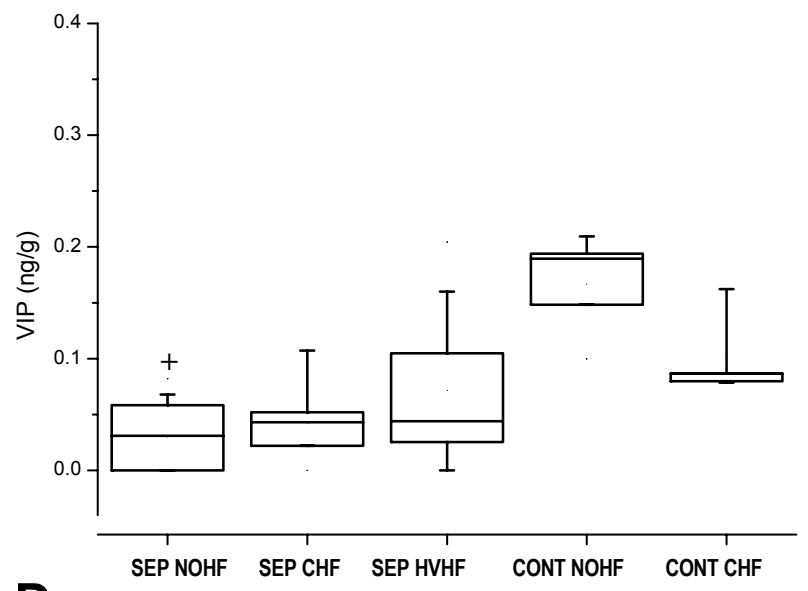

D

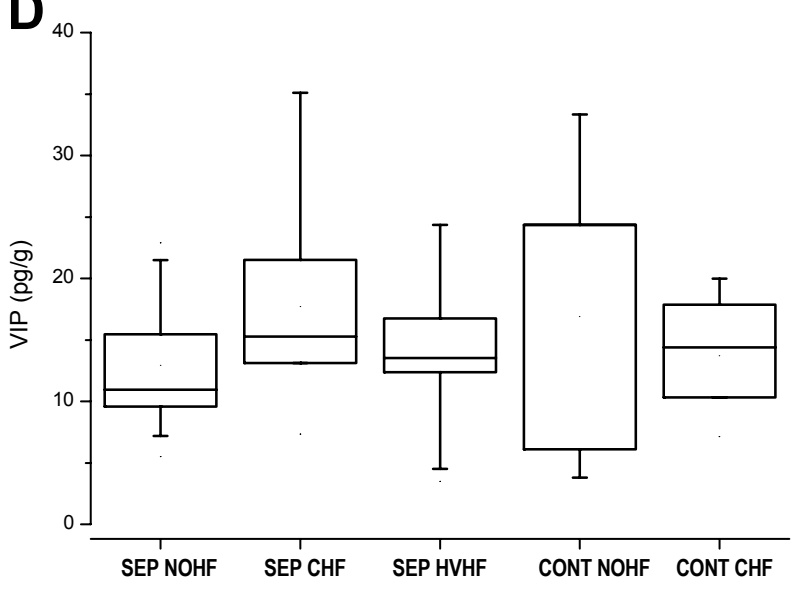

Fig. 1. (A) VIP concentrations in the plasma of the septic pigs without hemofiltration (SEP-NO HF), septic pigs with conventional hemofiltration (SEP-CHF), septic pigs with high-volume hemofiltration (SEP-HVHF). *Significant difference vs. baseline $(B ; p<0.05)$. (B-D) VIP concentrations in the coronary artery (B), mesenteric artery (C), and left ventricular free wall (D), in the control pigs without hemofiltration (CON-NO HF), control pigs with conventional hemofiltration (CON-CHF), septic pigs without hemofiltration (SEP-NO HF), septic pigs with conventional hemofiltration (SEP-CHF), septic pigs with high-volume hemofiltration (SEP-HVHF). Data are median and $25^{\text {th }}$ and $75^{\text {th }}$ percentiles. + significant difference vs CON-NO HF $(p<0.05)$. Note different Y-scales in A-D.

transport to storage sites, peptide release induced by the systemic inflammation and its degradation.

It has been recently reported that the activity of VIP-degrading enzyme, neutral endopeptidase, is diminished in the septic patients, which contributes to the decreased clearance of degraded peptides thus at least partly compensating for their increased need (Pirracchio et al. 2008).

It should be noted that neuropeptides, in contrast to classical neurotransmitters, are not synthesized in the nerve endings, but in the neuronal sommata and then they are transported to the site of their release by axonal transport. Realizing that the transport rate of VIP to nerve terminals is approximately $9 \mathrm{~mm} / \mathrm{h}$ and that the half-life of the peptide in the plasma is only $1 \mathrm{~min}$ (Henning and Sawmiller 2001), the decreasing plasma levels of the peptide could be associated with its compromised release from at least partially depleted tissue stores.

Circulating VIP is derived mainly from the enteric nervous system and vascular nerves that display variable density of the peptide-containing nerve fibers from rare (vessels in the skeletal muscles) to moderate (coronary arteries) and intense (mesenteric vasculature) (Opstad 1987, Owman 1990). VIP-ergic nerve fibers supplying the mesenteric artery in the pig extend from the enteric neurons (Shen et al. 1993) that display considerable plasticity in response to inflammation (Birch et al. 2008, Jacob et al. 2007, Pidsudko et al. 2008). Our study shows a significant increase in VIP concentration in the mesenteric artery of pig with peritonitis-induced sepsis, which could result from the progression of intraabdominal inflammation induced by inoculation of faeces. It has been already documented that bowel perforation leads to increased VIP expression in the myenteric plexus of 
human patients suffering from subsequent peritonitis (Jacob et al. 2007).

In contrast, coronary arteries of the septic pigs displayed significantly lower peptide levels than the respective controls. Concentrations of VIP in the left ventricular myocardium were negligible in both septic and control animals. In the heart, VIP originates from the parasympathetic postganglionic fibers and intrinsic nonadrenergic noncholinergic neuronal network (Anderson et al. 1993). The cardiac tissue does not normally metabolize VIP thus contributing to the systemic VIP levels by its lymphatic and coronary venous drainage (Anderson et al. 1993). Decreased concentration of VIP in the coronary artery after 22 hours of sepsis suggests that the peptide stores could be depleted within relatively short duration of the systemic inflammation and that VIP cannot be released from the coronary circulation in substantial amounts in further course of sepsis.

\section{Impact of blood purification techniques on VIP plasma and} tissue levels

Our study also indicates that hemofiltration in both settings did not significantly affect plasma VIP concentrations in any experimental group; however, a trend to decrease VIP levels in the vascular tissue could be observed both in control and septic animals.

VIP belongs to low molecular weight peptides (MW 3300 Da, Clark et al. 1999) that should be susceptible to filtration through the filter used in this study (cut off 30,000 Da). Indeed, after appropriate extraction and concentration, we have detected significant amounts of VIP in the ultrafiltrates that, when compared to peptide tissue content, could lead to at least partial depletion of VIP from its storage sites. Previously published studies on cytokine removal by continuous venovenous hemofiltration under conditions of sepsis mainly reported no change in plasma cytokine levels (Heering et al. 1997, Heering et al. 2003, Sykora et al. 2009) in spite of detectable levels of cytokines in the ultrafiltrate (Jiang et al. 2005) or their adsorption on the ultrafiltration membrane (Goldfarb and Golper 1994). These studies dealt with cytokines with substantially greater molecular weights than is that of VIP and they did not address cytokine tissue levels.

Two hypotheses have been suggested to explain the discrepancy between apparent removal of inflammatory cytokines by hemopurification techniques and no change in their systemic levels: in the threshold immunomodulation hypothesis proposed by Honoré and collaborators, both pro- and antiinflammatory mediators are removed at the interstitial and tissue levels and hemofiltration might facilitate mediator flow from tissues to the blood compartment (Honoré et al. 2007). In the mediator delivery hypothesis (Di Carlo and Alexander 2005), high-volume hemofiltration is thought to promote the lymphatic flow thus causing drag of mediators to the blood compartment for subsequent removal. Both theories suggest that significant amounts of mediators are removed from the sites of their production or accumulation.

\section{Study limitations}

Our study has some limitations related to the model designed to induce hyperdynamic sepsis with increasing severity over time, where standard antibiotic therapy that would attenuate the inflammatory response was not used. Therefore, the observation study time was relatively short (i.e. 22 hours) not allowing us to monitor VIP plasma and tissue levels in the later stages of sepsis, which could provide better insight into the changes of the peptide stores in relation to the course of the systemic inflammatory process. The true clinical consequences of the suspected peptide depletion due to hemofiltration could not be derived from the present data. However, remarkable effects of the peptide and its receptor agonists in the protection against endotoxemia has been repeatedly shown in experiments using in vivo VIP administration, inoculation of cells producing VIP, VIP receptor agonists and antagonists and VIP gene knockout mice that clearly demonstrated not only inhibitory effect of VIP and the related compounds on the release of TNF- $\alpha$, IL-6, IL-12 and $\mathrm{NO}$, but also significant increase in the survival rate of treated endotoxemic mice (Chorny and Delgado 2008, Delgado et al. 1999, Hamidi et al. 2006, Matínez et al. 2005). Nevertheless, relation of VIP plasma levels to the survival rate in human septic patients has not been established yet.

\section{Conclusion}

Taken together, this is the first report documenting the impact of hemofiltration on tissue stores of a substance that has multiple beneficial effects in body's defense against infection. Under septic conditions, peptide seems to be rapidly depleted from the coronary artery and, on the other hand upregulated in the mesenteric artery. Hemofiltration in both settings has tendency to drain away these upregulated tissue stores which could result in the limited secretory capacity of the peptide. 


\section{Conflict of Interest}

There is no conflict of interest.

\section{Acknowledgements}

The present study was supported by the Research project
MSM 0021620819: Replacement of and Support to Some Vital Organs awarded by the Ministry of Education, Youth and Sports of the Czech Republic. We thank Ing. Ladislav Trefil for expert technical assistance.

\section{References}

ANDERSON FL, KRALIOS AC, REID B, HANSON GR: Release of vasoactive intestinal peptide and neuropeptide Y from canine heart. Am J Physiol 265: H959-H965, 1993.

BELLINGER DL, LORTON D, ROMANO TD, OLSCHOWKA JA, FELTEN SY, FELTEN DL: Neuropeptide innervation of lymphoid organs. Ann N Y Acad Sci 594: 17-33, 1999.

BIRCH D, KNIGHT GE, BOULOS PB, BURNSTOCK G: Analysis of innervation of human mesenteric vessels in non-inflamed and inflamed bowel--a confocal and functional study. Neurogastroenterol Motil 20: 660-670, 2008.

BRANDTZAEG P, OKTEDALEN O, KIERULF P, OPSTAD PK: Elevated VIP and endotoxin plasma levels in human gram-negative septic shock. Regul Pept 24: 37-44, 1989.

CHAMPION HC, SANTIAGO JA, GARRISON EA, CHENG DY, COY DH, MURPHY WA, ASCUITTO RJ, ROSSASCUITTO NT, MCNAMARA DB, KADOWITZ PJ: Analysis of cardiovascular responses to PACAP-27, PACAP-38, and vasoactive intestinal polypeptide. Ann N Y Acad Sci 805: 429-441, 1996.

CHORNY A, DELGADO M: Neuropeptides rescue mice from lethal sepsis by down-regulating secretion of the lateacting inflammatory mediator high mobility group box 1. Am J Pathol 172: 1297-1307, 2008.

CHVOJKA J, SYKORA R, KROUZECKY A, RADEJ J, VARNEROVA V, KARVUNIDIS T, HES O, NOVAK I, RADERMACHER P, MATEJOVIC M: Renal haemodynamic, microcirculatory, metabolic and histopathological responses to peritonitis-induced septic shock in pigs. Crit Care 12: R164, 2008.

CLARK WR, HAMBURGER RJ, LYSAGHT MJ: Effect of membrane composition and structure on solute removal and biocompatibility in hemodialysis. Kidney Int 56: 2005-2015, 1999.

DELGADO M, POZO D, MARTINEZ C, LECETA J, CALVO JR, GANEA D, GOMARIZ RP: Vasoactive intestinal peptide and pituitary adenylate cyclase-activating polypeptide inhibit endotoxin-induced TNF-alpha production by macrophages: in vitro and in vivo studies. J Immunol 162: 2358-2367, 1999.

DI CARLO JV, ALEXANDER SR: Hemofiltration for cytokine-driven illnesses: the mediator delivery hypothesis. Int $J$ Artif Organs 28: 777-786, 2005.

DINARELLO CA: Anti-cytokine therapies in response to systemic infection. J Investig Dermatol Symp Proc 6: $244-$ 250, 2001.

FUORTES M, BLANK MA, SCALEA TM, POLLOCK TW, JAFFE BM: Release of vasoactive intestinal peptide during hyperdynamic sepsis in dogs. Surgery 104: 894-898, 1988.

GANEA D, DELGADO M: Vasoactive intestinal peptide (VIP) and pituitary adenylate cyclase-activating polypeptide (PACAP) as modulators of both innate and adaptive immunity. Crit Rev Oral Biol Med 13: 229-237, 2002.

GOLDFARB S, GOLPER TA: Proinflammatory cytokines and hemofiltration membranes. J Am Soc Nephrol 5: 228232, 1994.

HAMIDI SA, SZEMA AM, LYUBSKY S, DICKMAN KG, DEGENE A, MATHEW SM, WASCHEK JA, SAID SI: Clues to VIP function from knockout mice. Ann N Y Acad Sci 1070: 5-9, 2006.

HEERING P, GRABENSEE B, BRAUSE M: Cytokine removal in septic patients with continuous venovenous hemofiltration. Kidney Blood Press Res 26: 128-134, 2003.

HEERING P, MORGERA S, SCHMITZ FJ, SCHMITZ G, WILLERS R, SCHULTHEISS HP, STRAUER BE, GRABENSEE B: Cytokine removal and cardiovascular hemodynamics in septic patients with continuous venovenous hemofiltration. Intensive Care Med 23: 288-296, 1997.

HENNING RJ, SAWMILLER DR: Vasoactive intestinal peptide: cardiovascular effects. Cardiovasc Res 49: 27-37, 2001. 
HONORÉ PM, JOANNES-BOYAU O, GRESSENS B: Blood and plasma treatments: the rationale of high-volume hemofiltration. Contrib Nephrol 156: 387-395, 2007.

HOTCHKISS RS, KARL IE: The pathophysiology and treatment of sepsis. N Engl J Med 348: 138-150, 2003.

JACOB P, MUELLER MH, HAHN J, WOLK I, MAYER P, NAGELE U, HENNENLOTTER J, STENZL A, KONIGSRAINER A, GLATZLE J: Alterations of neuropeptides in the human gut during peritonitis. Langenbecks Arch Surg 392: 267-271, 2007.

JIANG HL, XUE WJ, LI DQ, YIN AP, XIN X, LI CM, GAO JL: Influence of continuous veno-venous hemofiltration on the course of acute pancreatitis. World J Gastroenterol 11: 4815-4821, 2005.

KALFIN R, MAULIK N, ENGELMAN RM, CORDIS GA, MILENOV K, KASAKOV L, DAS DK: Protective role of intracoronary vasoactive intestinal peptide in ischemic and reperfused myocardium. J Pharmacol Exp Ther 268: 952-958, 1994.

KAWASHIMA K, YOSHIKAWA K, FUJII YX, MORIWAKI Y, MISAWA H: Expression and function of genes encoding cholinergic components in murine immune cells. Life Sci 80: 2314-2319, 2007.

KULKARNI-NARLA A, BEITZ AJ, BROWN DR: Catecholaminergic, cholinergic and peptidergic innervation of gutassociated lymphoid tissue in porcine jejunum and ileum. Cell Tissue Res 298: 275-286, 1999.

LUNDBERG JM: Pharmacology of cotransmission in the autonomic nervous system: integrative aspects on amines, neuropeptides, adenosine triphosphate, amino acids and nitric oxide. Pharmacol Rev 48: 113-178, 1996.

LV B, TANG Y, CHEN F, XIAO X: Vasoactive Intestinal Peptide and pituary adenylate cyclase-activating polypeptide inhibit tissue factor expression in monocyte in vitro and in vivo. Shock 31: 185-191, 2009.

MARTÍNEZ C, ARRANZ A, JUARRANZ Y, ABAD C, GARCÍA-GÓMEZ M, ROSIGNOLI F, LECETA J, GOMARIZ RP: PAC1 receptor: emerging target for septic shock therapy. Ann N Y Acad Sci 1070: 405-410, 2006.

MARTÍNEZ C, JUARRANZ Y, ABAD C, ARRANZ A, MIGUEL BG, ROSIGNOLI F, LECETA J, GOMARIZ RP: Analysis of the role of the PAC1 receptor in neutrophil recruitment, acute-phase response, and nitric oxide production in septic shock. J Leukoc Biol 77: 729-738, 2005.

MATEJOVIC M, KROUZECKY A, MARTINKOVA V, ROKYTA R Jr, KRALOVA H, TRESKA V, RADERMACHER P, NOVAK I: Selective inducible nitric oxide synthase inhibition during long-term hyperdynamic porcine bacteremia. Shock 21: 458-465, 2004.

OPSTAD PK: The plasma vasoactive intestinal peptide (VIP) response to exercise is increased after prolonged strain, sleep and energy deficiency and extinguished by glucose infusion. Peptides 8: 175-178, 1987.

OWMAN C: Peptidergic vasodilator nerves in the peripheral circulation and in the vascular beds of the heart and brain. Blood Vessels 27: 73-93, 1990.

PIDSUDKO Z, KALECZYC J, WASOWICZ K, SIENKIEWICZ W, MAJEWSKI M, ZAJAC W, LAKOMY M: Distribution and chemical coding of intramural neurons in the porcine ileum during proliferative enteropathy. J Comp Pathol 138: 23-31, 2008.

PIRRACCHIO R, DEYE N, LUKASZEWICZ AC, MEBAZAA A, CHOLLEY B, MATÉO J, MÉGARBANE B, LAUNAY JM, PEYNET J, BAUD F, PAYEN D: Impaired plasma B-type natriuretic peptide clearance in human septic shock. Crit Care Med 36: 2542-2546, 2008.

RATANARAT R, BRENDOLAN A, PICCINNI P, DAN M, SALVATORI G, RICCI Z, RONCO C: Pulse highvolume haemofiltration for treatment of severe sepsis: effects on hemodynamics and survival. Crit Care 9: R294-R302, 2005.

REEVES JH, BUTT WW, SHANN F, LAYTON JE, STEWART A, WARING PM, PRESNEILL JJ: Continuous plasmafiltration in sepsis syndrome. Plasmafiltration in Sepsis Study Group. Crit Care Med 27: 2096-2104, 1999.

REVHAUG A, LYGREN I, LUNDGREN TI, ANDERSEN OK, BURHOL PG, GIERCKSKY KE: Increased plasma levels of vasoactive intestinal polypeptide in pigs during endotoxinaemia. Eur Surg Res 17: 75-82, 1985.

RONCO C, TETTA C, MARIANO F, WRATTEN ML, BONELLO M, BORDONI V, CARDONA X, INGUAGGIATO P, PILOTTO L, D'INTINI V, BELLOMO R: Interpreting the mechanisms of continuous renal replacement therapy in sepsis: the peak concentration hypothesis. Artif Organs 27: 792-801, 2003. 
SHEN Z, KLÖVER-STÅHL B, LARSSON LT, MALMFORS G, EKBLAD E, SUNDLER F: Peptide-containing neurons remain unaffected after intestinal autotransplantation: an experimental study in the piglet. Eur $J$ Pediatr Surg 3: 271-277, 1993.

SYKORA R, CHVOJKA J, KROUZECKY A, RADEJ J, KARVUNIDIS T, VARNEROVA V, NOVAK I, MATEJOVIC M: High versus standard-volume haemofiltration in hyperdynamic porcine peritonitis: effects beyond haemodynamics? Intensive Care Med 35: 371-380, 2009.

TOSCANO MG, DELGADO M, KONG W, MARTIN F, SKARICA M, GANEA D: Dendritic cells transduced with lentiviral vectors expressing VIP differentiate into VIP-secreting tolerogenic-like DCs. Mol Ther 18: 1035$1045,2010$. 